$\xi=-1$

\title{
Optimization of Supercritical Extraction Conditions of Senna Alata and Evaluation of Biological Activity
}

\author{
Istikamah Subuki $^{1 *}$, Aiman Nabilah Abdul Malek ${ }^{1}$, Saidatul Husni Saidin ${ }^{2}$, Mazura Md. Pisar ${ }^{2}$ \\ ${ }^{I}$ Fakulti Kejuruteraan Kimia, Universiti Teknologi MARA, Shah Alam, 40450, Selangor, Malaysia; \\ ${ }^{2}$ Forest Research Institute Malaysia (FRIM), 52109 Kepong, Selangor Darul Ehsan, Malaysia; \\ *Corresponding author E-mail: istikamah@salam.uitm.edu.my
}

\begin{abstract}
Supercritical fluid extraction (SFE) offer faster extraction process, decreased solvent usage and more selectivity on desired compounds. In this present study, the influence of pressure (100, 200 and 300 bar) and temperature $\left(40,50\right.$ and $\left.60^{\circ} \mathrm{C}\right)$ on the Senna alata crude yield were investigated with fixed supercritical carbon dioxide $\left(\mathrm{SC}-\mathrm{CO}_{2}\right)$ at the flow rate of $35 \mathrm{~g} / \mathrm{min}$. The parameters were optimised and modelled using response surface methodology (RSM) and central composite design (CCD). The analysis of variance (ANOVA) experimental design consists of 13 experimental runs with 5 replicates at the central points. Well-fitting quadratic model were successfully established for crude extract through backward elimination. The optimum crude extract yield pointed out by RSM was at the pressure of 300 bar and temperature $40^{\circ} \mathrm{C}$ respectively. Extraction yields based on $\mathrm{SC}-\mathrm{CO}_{2}$ varied in the range of 0.28 to $3.62 \%$. The highest hyaluronidase inhibition activity and total flavonoids content obtained by S.alata crude extracts were $41.19 \%$ and $52.53 \%$ w/w, respectively. $\mathrm{SC}-\mathrm{CO}_{2}$ proves to have great potential for extraction of yield, hyaluronidase inhibition activity and total flavonoids content for S.alata.
\end{abstract}

Keywords: Supercritical carbon dioxide conditions; hyaluronidase activity; total flavonoids content.

\section{Introduction}

Extraction method and extracting solvent are important for quantity and quality of extracts. Hence, appropriate extraction method for each plant should be applied to obtain the highest amount of bioactive compounds. Sequential extractions using solvents such as petroleum ether, chloroform, methanol and ethanol have been found to be effective against pathogenic bacteria (Chatterjee et al., 2012; Gritsanapan \& Mangmeesri, 2009; Ehiowemwenguan et al., 2014; Hong \& Lyu, 2011) as well as against a few fungi that could cause dermatophytic diseases such as C. albicus, T. mentagrophyte, A. niger, D. congolensis, C. albicans etc (Alalor et al., 2012; Ali-Emmanuel et al., 2003; Owoyale et al., 2005). However, recent studies have shown that supercritical fluid extraction (SFE) offers vast difference over solvent-based extraction techniques. Compared to the conventional solvent method, extraction via supercritical fluid provides the following advantages: faster extraction process, more selectivity of desired compounds, decreased solvent usage and lower costs for solvent disposal (Wright \& DePhillipo, 2015; David \& Selber, 1996). In addition, SFE requires very little to no dry-down time prior to the analysis and hence limits the thermal degradation (Capuzzo et al., 2013). There are many literature about the natural materials extraction with SFE such as Marchantia convoluta (Chinese herb) (Xiao et al., 2007). SFE of plant material is a growing topic of interest with solvents such as carbon dioxide $\left(\mathrm{CO}_{2}\right)$, propane, butane or ethylene. It allows separation by using the supercritical fluid as the solvent. A substance is considered to be in supercritical condition when it is above its critical temperature and critical pressure. The main and commonly used solvent is $\mathrm{CO}_{2}$. It is a cheap, eco-friendly, and generally recognised as a safe component. SFE using $\mathrm{CO}_{2}$ is also attractive because of its high diffusivity and allows the extraction of easily oxidised compounds in natural products (David \& Selber, 1996; Xiao et al., 2007; Wright \& DePhillipo, 2015). However, conventional supercritical fluid carbon dioxide $\left(\mathrm{SC}-\mathrm{CO}_{2}\right)$ suffers from low polarity which affects the efficiency of extracting the compound of interest.

The genus Senna (Fabaceae) is represented in Southern North America, Brazil by its beautiful yellow flowering shrub that grows about 1 to $2 \mathrm{~m}$ in height. It produces a wide range of bioactive molecules that can be found mainly in its leaves rather than its flowery shrub, making it a rich source for various types of antiinflammatory and antibacterial traditional medicines. Thus S.alata plays an important role in drug development in pharmaceutical industries. It has been cultivated to treat skin diseases, ringworms, fever, constipation etc. (Mohideen et al., 2005). The main activity of its leaves is associated with the presence of numerous active chemical components such as phenols, tannins, saponins, alkaloids, steroids, flavonoids and carbohydrates. The major technical challenge in the application of extraction process using supercritical fluid is optimising variable combinations of temperature and pressure to increase in the solvent's effectiveness (David and Selber, 1996).

Hence, this paper is to investigate and optimise important variables such as pressure and temperature of the supercritical fluid carbon dioxide extraction of S.alata as well as to discover the relationship of the variables with hyaluronidase inhibitory activity and total flavonoid contents. 


\section{Methodology}

\subsection{Chemicals and Materials}

Dried samples of Senna alata was purchased from HERBagus Sdn. Bhd., Penang. Hyaluronidase (bovine testes, type 1-S), hyaluronic acid (rooster comb), bovine serum albumin (BSA) and ammonium acetate were purchased from Sigma Chemical Co. Apigenin was isolated from parsley through acid hydrolysis of apiin.

\subsection{Extraction Preparation}

S.alata extraction was carried out in a batch system using Supercritical Fluid Extraction (SFE) system (SFE 500MR, Thar Technology) including $500 \mathrm{~mL}$ stainless steel extraction vessel, automated back pressure regulator (ABPR) and, a high pressure pump. Figure 3.1 shows the scheme of supercritical $\mathrm{CO}_{2}$ apparatus. A supercritical non-polar extracting solvent such as carbon dioxide $\left(\mathrm{CO}_{2}\right)$ was used for extraction system. $130 \mathrm{~g}$ of sample was charged to the extraction vessel. After recirculating chiller to $3^{\circ} \mathrm{C}$, the $\mathrm{CO}_{2}$ gas was liquefied and continuously supplied into the extraction vessel using a high-pressure pump. Experimental extraction condition were optimised according to Xiao et al. (2007) with minor modifications between two parameters; pressure and temperature. Supercritical fluid extractions were conducted at pressures of 100,200 and 300 bar while 40,50 and $60^{\circ} \mathrm{C}$ for temperatures, respectively. The supercritical $\mathrm{CO}_{2}$ was maintained at 35 $\mathrm{g} / \mathrm{min}$. The S.alata samples were soaked in the solvent for $30 \mathrm{~min}$ (static extraction) to equilibrate the mixture at desired temperature and pressure (Bimakr et al., 2013). The static extraction time was applied for each run at respected temperature and pressure. Released solutes containing $\mathrm{CO}_{2}$ extracts was collected after the dynamic extraction time (1 hour) and into a pre-weighed flask. The fixed dynamic extraction time was applied for each run.

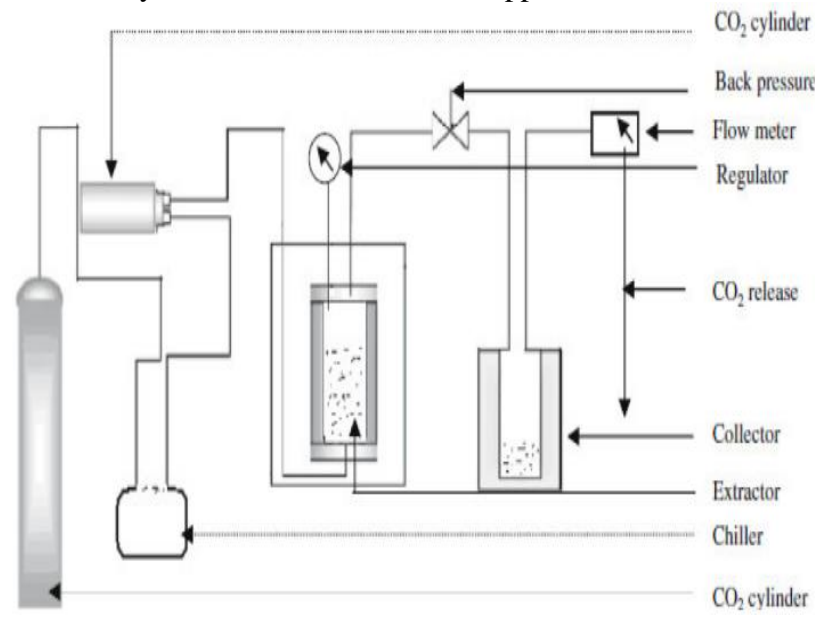

Fig. 1: Supercritical $\mathrm{CO}_{2}$ apparatus (Pradhan et al., 2010).

\subsection{Measurement of Crude Extraction Yield (CEY)}

The extracts were weighed gravimetrically and then the CEY was calculated according to the following equation:

$$
C E Y=\frac{m_{e}}{m_{s}} \times 100 \%
$$

where $m_{e}$ is the crude extract mass $(\mathrm{g})$ and $\mathrm{m}_{\mathrm{s}}$ is the dried sample mass $(\mathrm{g})$. The measurement was performed in triplicate and the mean values of CEY were expressed in percent (g-extract/g-dried sample).

\subsection{Optimization Analysis with RSM}

The SC- $\mathrm{CO}_{2}$ extraction parameters were optimised by applying response surface methodology (RSM). The parameters which included include pressure $(100-300 \mathrm{bar})$ and temperature $\left(40^{\circ} \mathrm{C}\right.$ $60^{\circ} \mathrm{C}$ ) were varied to achieve the highest amount of crude oil from S.alata sample. A central composite design (CCD) with 4 axial points and 5 central points were used for designing the experimental data. The mathematical model for each run were predicted using multiple regression model and the following second-order polynomial model was fitted to the data:

$Y=\beta_{0}+\sum_{j=1}^{k} \beta_{j} X_{j}+\sum_{j=1}^{k} \beta_{j j} X_{j}^{2}+\sum_{i=1}^{j-1} \sum_{j=2}^{k} \beta_{i j} X_{i} X_{j}$

where $\mathrm{Y}$ is predicted response, $\beta_{0}$ is offset term, $\beta_{\mathrm{j}}$ is the regression coefficients for linear effect term, $\beta_{\mathrm{jj}}$ is quadratic effects and $\beta_{\mathrm{ij}}$ is interaction effects. In this model, $\mathrm{Xj}$ and $\mathrm{Xi}$ are the independent variables. The experimental data for each run was analysed for the F-test of significance and was refitted only to significance higher than or equal to $5 \%(\mathrm{p} \leq 0.05)$ (Paulucci et al., 2013). The model adequacy was then determined using the coefficient of determination $\left(\mathrm{R}^{2}\right)$. Lastly, an optimisation was carried out to interpret the optimal level of independent variables achieving the maximum desired response goal.

\subsection{Hyaluronidase Assay}

The assay was performed according to Sigma-Aldrich protocol with slight modifications (Ling et al., 2003). The assay medium containing hyaluronidase in cold $20 \mathrm{mM}$ sodium phosphate buffer $\left(\mathrm{pH} 7\right.$ at $37^{\circ} \mathrm{C}$ ) with $77 \mathrm{mM}$ sodium chloride and $0.01 \%(\mathrm{w} / \mathrm{v})$ BSA was pre-incubated with $25 \mu \mathrm{L}$ of sample compound (in DMSO) for $10 \mathrm{~min}$ at $37^{\circ} \mathrm{C}$.Then the incubated assay was mixed with $0.03 \%(\mathrm{w} / \mathrm{v})$ hyaluronic acid solution in $300 \mathrm{mM}$ sodium phosphate $\left(\mathrm{pH} 5.35\right.$ at $37^{\circ} \mathrm{C}$ ) and incubated further for $45 \mathrm{~min}$ at $37^{\circ} \mathrm{C}$. The reaction mixture was precipitated with $1 \mathrm{~mL}$ of $0.1 \%$ BSA in $24 \mathrm{mM}$ sodium acetate and $79 \mathrm{mM}$ acetic acid (pH 3.75) (Acid albumin solution). After standing at room temperature for $10 \mathrm{~min}$, the absorbance of the reaction mixture was measured at $600 \mathrm{~nm}$. The reference value for maximum inhibition was held for absorbance in the absence of enzyme. The inhibitory activity of sample compound was calculated as the percentage ratio of the absorbance in the presence of sample compound versus in the absence of enzyme. The enzyme activity was checked by preincubating the enzyme in DMSO and following the procedures above. The percentage ratio of the absorbance of the presence of enzyme versus absence of enzyme should be $15-20 \%$. The performance of the assay was verified using apigenin as a reference following the same procedures. The results were expressed as the mean of the Mean \pm SEM. of three independent experiments measured in triplicates.

\subsection{Total Flavonoids Content}

Flavonoids content was determined by aluminium chloride colorimetric method (Chang et al., 2002) with a bit of modification. 0.5 $\mathrm{mL}$ of sample extract was mixed with $1.5 \mathrm{~mL}$ methanol, $0.1 \mathrm{~mL}$ $10 \%$ aluminium chloride, $0.1 \mathrm{~mL} 1 \mathrm{M}$ potassium acetate and 28 $\mathrm{mL}$ distilled water. After standing at room temperature for $30 \mathrm{~min}$, the absorbance was measured at $415 \mathrm{~nm}$. The calibration curve was prepared by using rutin at concentrations of 10 to $50 \mathrm{ppm}$ in methanol. Total flavonoids content were expressed as a percentage of the weight of rutin equivalent to the dry weight of the sample $(\% \mathrm{w} / \mathrm{w})$. 


\section{Results and Discussion}

\subsection{Response Surface Methodology}

For this study, central composite design (CCD) was applied to model the $\mathrm{CEY}$ by using $\mathrm{SC}-\mathrm{CO}_{2}$ extraction. 13 experiments were assigned which included 4 axial points, 4 factorial points and 5 central points based on the CCD. Two factors (pressure and temperature) were set and three level code values $(-1,0,+1)$ CCD was assigned to determine the most practical and desirable combination effect of both extraction parameters. The layout of the CCD and the results obtained with each run are illustrated in Table 1. The results showed that the yield of S.alata crude extract, generated from different combinations of extraction conditions via SC$\mathrm{CO}_{2}$ was found

Table 1: Effect of extraction pressure and temperature on the crude extraction yield of S.alata by supercritical fluid extraction with carbon dioxide

\begin{tabular}{|l|l|l|l|l|l|}
\hline \multirow{2}{*}{ Run } & \multicolumn{2}{|c|}{ Coded parameter } & \multicolumn{2}{|c|}{$\begin{array}{c}\text { Actual parameter } \\
\text { values }\end{array}$} & $\begin{array}{l}\text { Crude } \\
\text { extraction yield } \\
(\%)\end{array}$ \\
\cline { 2 - 5 } & A & B & A & B & 1.19 \\
\hline 1 & -1 & -1 & 100.00 & 40.00 & 19 \\
\hline 2 & 0 & -1 & 200.00 & 40.00 & 2.31 \\
\hline 3 & -1 & +1 & 100.00 & 60.00 & 0.94 \\
\hline 4 & 0 & 0 & 200.00 & 50.00 & 1.21 \\
\hline 5 & +1 & 0 & 300.00 & 50.00 & 3.61 \\
\hline 6 & +1 & +1 & 300.00 & 60.00 & 3.62 \\
\hline 7 & 0 & 0 & 200.00 & 50.00 & 1.23 \\
\hline 8 & 0 & 0 & 200.00 & 50.00 & 1.26 \\
\hline 9 & 0 & +1 & 200.00 & 60.00 & 0.92 \\
\hline 10 & -1 & 0 & 100.00 & 50.00 & 1.09 \\
\hline 11 & +1 & -1 & 300.00 & 40.00 & 3.59 \\
\hline 12 & 0 & 0 & 200.00 & 50.00 & 1.25 \\
\hline 13 & 0 & 0 & 200.00 & 50.00 & 1.27 \\
\hline
\end{tabular}

to be from 0.28 to $3.62(\%)$. By using multiple regression analysis, the best fitting models were determined with backward elimination. Analysis of variance (ANOVA) was used to estimate the significant relationships of the main effects and interactions. ANOVA for response surface quadratic models determined that the models were significant with $\mathrm{P}<0.05$. The validity of data depended on the high coefficient of determination $R_{2}$ and the adjusted $R_{2}$. Adjusted $R_{2}$ is a measure of the amount of variation about the mean explained by the quadratic model (Kar et al., 2009). The accuracy of the empirical model to actual data can be indicated with value $\mathrm{R}_{2}$ being closer to unity (Zhang et al., 2007). In other words, the regression model can be considered as giving a good response to the statistical data if the value for the response variable was higher than $0.75 \%$. In this case, the $\mathrm{R}_{2}$ value for CEY was 0.9534 while adjusted $R_{2}$ was 0.9202 , which indicates that the regression model is a good fit. This also means that the $R_{2}$ specifies $95.34 \%$ of CEY is correlated with the independent variables and only $4.66 \%$ of the total variations could not be explained by the model. The simultaneous rise of both $\mathrm{R}_{2}$ and adjusted $\mathrm{R}_{2}$ in the data indicates the accuracy and is a good estimation of it. ANOVA (Table 2) also showed that quadratic regression models for crude recovery were significant with $\mathrm{P}>0.0002$.

Table 2: ANOVA for response surface quadratic model for crude extraction yield by supercritical fluid extraction with carbon dioxide.

\begin{tabular}{|l|l|l|l|l|l|}
\hline Source & $\begin{array}{l}\text { Sum of } \\
\text { squares }\end{array}$ & $\begin{array}{l}\text { Degree of } \\
\text { freedom }\end{array}$ & $\begin{array}{l}\text { Mean } \\
\text { square }\end{array}$ & $\begin{array}{l}\text { F } \\
\text { value }\end{array}$ & Prob>F \\
\hline Model & 13.34 & 5 & 2.67 & 28.67 & 0.0002 \\
\hline Residual & 0.65 & 7 & 0.093 & & \\
\hline $\begin{array}{l}\text { Lack of } \\
\text { Fit }\end{array}$ & 0.65 & 3 & 0.22 & 374 & $<0.0001$ \\
\hline $\begin{array}{l}\text { Pure } \\
\text { error }\end{array}$ & 0.0023 & 4 & 0.00058 & & \\
\hline Total & 13.99 & 12 & & & \\
\hline
\end{tabular}

and Manohar (2014) studied the supercritical carbon dioxide extraction from Mango Ginger Rhizome to optimise the amount of total extraction yield and total phenolic content by RSM. They found that the extraction yield increased with higher temperature and pressure simultaneously due to increasing in the vapour pressure of active components in the extract. Figure $2 b$ shows that the CEY decreased gradually from low to high level $(-1$ to +1$)$ of temperature $\left(\mathrm{B}: 40^{\circ} \mathrm{C}\right.$ to $\left.60^{\circ} \mathrm{C}\right)$. The yield decreased may be due to reduced density of carbon dioxide as the temperature rises (Abdalbasit et al., 2010). The pressure (A) and quadratic terms for pressure $\left(\mathrm{A}_{2}\right)$ has significant positive effect on $C E Y$ due to the $P$ values being well below the 0.05 significance level (Table 3), while the temperature $(\mathrm{B})$ and quadratic terms for temperature $\left(\mathrm{B}_{2}\right)$ 
have a negative effect on the CEY. Although temperature (B), combination terms of pressure and temperature $(\mathrm{AB})$ and quadratic terms for temperature $\left(B_{2}\right)$ have an insignificant $(P>0.05)$ effect on CEY, they were not removed by backward elimination to support the hierarchy of the model.

To evaluate the interaction between pressure and temperature on the CEY, response surface plot was constructed at a constant carbon dioxide flow rate at $35 \mathrm{~g} / \mathrm{min}$ (Figure 3 ). The predictive model was constructed using the actual levels of the studied factors. Based on the response surface plot, it was shown that CEY increased at high level (+1) of pressure (300 bar) and low level (-1) of temperature $\left(40^{\circ} \mathrm{C}\right)$. The CEY is decreased when pressure is below high level (+1) and temperature is beyond the low level (-1). Response surface was constructed based on the second order polynomial equation by backward elimination:

$$
Y=+9.10-0.03 A-0.23 B+7 E^{-5} A B+9.20 E^{-5} A^{2}+1.85 E^{-3} B^{2}
$$

\subsection{Optimisation of Crude Extraction Yield}

High yields of plant extracts are extensively obtained by SFE using carbon dioxide as the solvent that is nontoxic, non-flammable,

Table 3: Regression coefficient model and $\mathrm{P}$ values for supercritical fluid extraction crude extraction yield by backward elimination.

\begin{tabular}{|l|c|c|}
\hline \multicolumn{1}{|c|}{ Variables } & Regression coefficient & P values* \\
\hline Intercept & 1.30 & 0.0002 \\
\hline $\mathrm{A}$ & 1.27 & $<0.0001$ \\
\hline $\mathrm{B}$ & -0.27 & 0.0681 \\
\hline $\mathrm{AB}$ & 0.07 & 0.6602 \\
\hline $\mathrm{A}^{2}$ & 0.92 & 0.0015 \\
\hline $\mathrm{B}^{2}$ & 0.18 & 0.3479 \\
\hline $\mathrm{A}:$ Pressure, B: Temperature \\
\hline *P $<0.05$
\end{tabular}

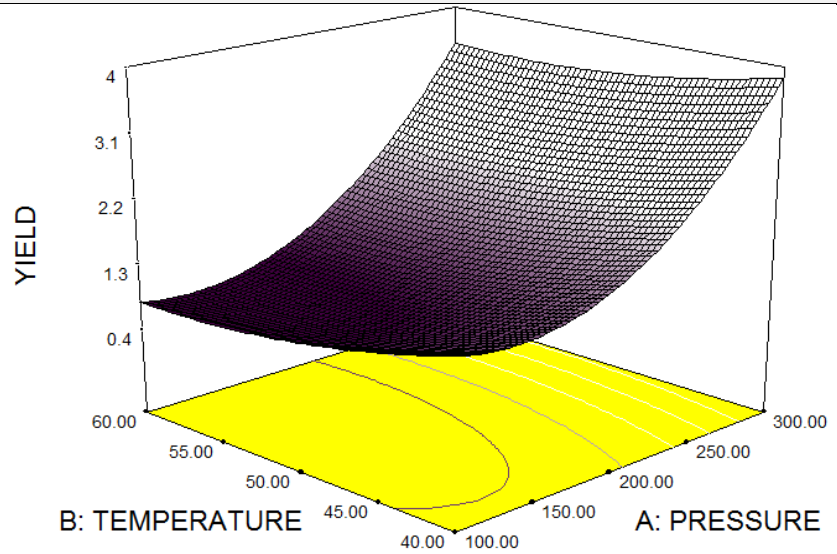

Fig. 3: Response surface plot of interaction between pressure (A) and temperature (B) on crude extraction yield.

Kar et al., 2009). For extraction parameters, the response surface cheap and available at a high degree of purity (Siddiq et al., 2010; indicated that an optimal point for CEY $(3.59 \%)$ was obtained with pressure (A) and temperature (B) at 300 bar and $40^{\circ} \mathrm{C}$, respectively. Further rise in temperature did not increase the CEY. However, the influence of temperature is a rather complex topic. As studied by Lepoyevic et al. (2017), rise in temperature could decrease the density of $\mathrm{CO}_{2}$ which could lead to a decrease in solubility of the solute. However, increasing temperature would raise the vapour pressure of solute which contributes to potential safety hazard at atmospheric pressure. Hence, it is practical to lower the extraction temperature. From an economic point of view, the investment in energy to provide the desired temperature for extraction can be lessened. Siti Hafsah et al. (2016) also warned that the use of extraction temperature above $100^{\circ} \mathrm{C}$ could lead to thermal degradation of desired compounds in the extract and is inappropriate for long-term application of $\mathrm{SC}-\mathrm{CO}_{2}$. Menichini et al. (2011) have investigated the optimal conditions to extract volatile oil from Citrus medica L. cv with extraction pressure and tem- perature of 100 to $300 \mathrm{bar}$ and $40^{\circ} \mathrm{C}$ to $60^{\circ} \mathrm{C}$, respectively. The highest yield of targeted compounds (Citropten, 2,3Dihydrobenzofuran and 2,3-Dihydro-3,5-dihydroxy-6-methyl-4HPyran4-one) was at the optimal condition of $40^{\circ} \mathrm{C}$ and 100 bar. Therefore, the optimal extracting temperature was selected at $40^{\circ} \mathrm{C}$ for this experimental study. On the other hand, the optimal extracting pressure was 300 bar. Although it is clearly evident that pressure increases the extraction yield greater than temperature, further study may be required to investigate the increment of CEY on increasing extracting pressure to increase the solubility of carbon dioxide in plants (Siti Hafsah et al., 2016). This case is also reported by Gopalan et al. (2000). However, it is not advisable to use very high extraction pressure as it could be a potential safety hazard due to high vapor pressure at room temperature (Mirofci, 2014).

The $\mathrm{SC}-\mathrm{CO}_{2}$ parameters were optimised using the numerical optimisation function of Design Expert. The combination of factors can maximise the crude extraction yield. The experiments using extraction conditions based on this optimal point were performed in order to confirm the predicted results of the optimised model. The predicted and experimental values of CEY obtained from Equation 2 are illustrated in Table 4. The statistical model was generated using the experimental values for the experimental parameters. The accuracy of the predicted value for CEY was $3.87 \%$ while the actual

Table 4: The difference between the experimental and predicted values for crude extraction recovery.

\begin{tabular}{|l|l|l|l|}
\hline \multicolumn{2}{|l|}{ Description } & \multicolumn{2}{l|}{ Crude extraction yield (\%) } \\
\hline Pr (bar) & Temp $\left({ }^{\circ} \mathrm{C}\right)$ & Experimental & Predicted \\
300 & 40 & 3.59 & 3.87 \\
\hline
\end{tabular}

experimental result was $3.59 \%$. Predicted and experimental values showed a good correlation which validated that the response model was suitable for the desired optimisation.

The efficiency of extraction yield depends on multiple extracting parameters such as pressure, temperature, solvent flow rate, extraction time (dynamic and static) and solvent polarity among others (Montgomery, 2001). The size of particles can also affect the crude/oil yield and extraction rate due to internal mass transfer limitations. Hence, to obtain high recovery of crude/oil, the plant needs to be ground prior to $\mathrm{SC}-\mathrm{CO}_{2}$ extraction. This is because smaller particles are able to increase the surface area for the solvent to solubilise into the structure and ruptures a large number of cell walls (Kar et al., 2009). The low yield of crude extract in this study could be attributed to the low ability of solvent channeling through the bed of ground S.alata leaves.

For a given pressure and temperature, the extraction yields may also increase in the presence of co-solvent (Mirofci, 2014). The added co-solvent may enhance the extraction yields as a result of interactions between the polar group and changes in local density, as well as an improvement for the cutbacks of supercritical fluid extraction carbon dioxide to extract polar components. Mirofci (2014) claimed that the yield is lower (only 1.5\%) when using supercritical carbon dioxide without co-solvent. The addition of co-solvent methanol and ethanol leads to improvement of the extraction yield (5.56\% and 5.54\% respectively). This may occur due to the polarity of co-solvent that separates the polar compounds from materials effectively.

\subsection{Biological Analysis}

This study examined the hyaluronidase inhibiting potential and the total flavonoid content of dried S.alata which is widely known as a traditional cure for inflammatory disease and effective antioxidant activity. The hyaluronidase assay used to determine hyaluronidase inhibition activity is a simple standard that provide strong and reproducible activity validation (Sumantran et al., 2007). Dried S.alata was extracted with supercritical carbon dioxide at a flow rate of $35 \mathrm{~g} / \mathrm{min}$. The parameters pressure (100 to $300 \mathrm{bar}$ ) and temperature $\left(40^{\circ} \mathrm{C}\right.$ to $\left.60^{\circ} \mathrm{C}\right)$ were varied. In contrast, most of the biological activity studies on S.alata have been extracted by solvent extraction method such as methanol and ethanol, which is 
super effective but endangere the environment (Marco et al., 1998; David \& Seber, 1996; Pharkphoom et al., 2009). Hence, this study will be the first to investigate the hyaluronidase activity and total flavonoid contents of S.alata crude extract with recent extraction technology of environmentally-safe supercritical fluid extraction by carbon dioxide.

The results obtained are tabulated in Table 5. As shown in Table 5, S.alata showed a varying degrees of hyaluronidase inhibition activity (ranging from $7.08-41.19 \%$ ) at final concentration of $100 \mu \mathrm{g} / \mathrm{mL}$. The most potent inhibitory activity was obtained at pressure and temperature of $200 \mathrm{bar}$ and $60^{\circ} \mathrm{C}$, shown in Figure 4 . The results clearly imparted that S.alata possesses noticeable hyaluronidase inhibition activity. It is known that hyaluronidase plays a crucial function in many biological systems, such as allergy and inflammation, by provoking the expression of anti- inflammatory genes, granulation of mast cells and release of chemical mediators (Nor Hayati et al., 2016; Sahasrabudhe \& Deodhar, 2010). Further, inhibitory effect by potent inhibitors possesses great antiarthritic abilities (Sahasrabudhe \& Deodhar, 2010). Since hyaluronic acid (HA) is naturally occurring in connective tissues, synovial fluid, umbilical cords and chicken combs, its degradation by hyaluronidase is linked to ophthalmic surgery for increase tissue permeability which is highly significant to speed up drug dispersion and delivery

Table 5: Hyaluronidase inhibition activity and flavonoid contents of S.alata.

\begin{tabular}{|c|c|c|c|c|}
\hline \multirow[t]{2}{*}{ Sample } & \multicolumn{2}{|c|}{ Description } & \multirow{2}{*}{$\begin{array}{l}\text { Hyaluronidase } \\
\text { Inhibition } \\
\text { Activity }(\%)\end{array}$} & \multirow{2}{*}{$\begin{array}{l}\text { Flavonoids } \\
\text { content } \\
(\% \mathrm{w} / \mathrm{w})\end{array}$} \\
\hline & $\begin{array}{l}\begin{array}{l}\text { Pressure } \\
\text { (bar) }\end{array} \\
\end{array}$ & $\begin{array}{l}\text { Temperature } \\
\left({ }^{\circ} \mathrm{C}\right)\end{array}$ & & \\
\hline 1 & 100 & 40 & $22.6105 \pm 0.69$ & 12.9904 \\
\hline 2 & 100 & 50 & $7.6353 \pm 0.28$ & 44.9957 \\
\hline 3 & 100 & 60 & $32.0633 \pm 2.19$ & $\mathrm{ND}$ \\
\hline 4 & 200 & 40 & $7.0817 \pm 2.75$ & 26.1690 \\
\hline 5 & 200 & 50 & $25.8434 \pm 2.65$ & 18.6384 \\
\hline 6 & 200 & 60 & $41.1888 \pm 2.39$ & 12.9904 \\
\hline 7 & 300 & 40 & $29.4107 \pm 1.82$ & 41.2304 \\
\hline 8 & 300 & 50 & $29.4704 \pm 2.40$ & 24.2864 \\
\hline 9 & 300 & 60 & $26.0324 \pm 2.39$ & 52.5263 \\
\hline
\end{tabular}

${ }^{a}$ Values are expressed as mean inhibition (\%) \pm SEM of triplicate measurements from 3 independent experiments. Final concentration of tested samples in reaction mixture was fixed at $100 \mu \mathrm{g} / \mathrm{mL}$.

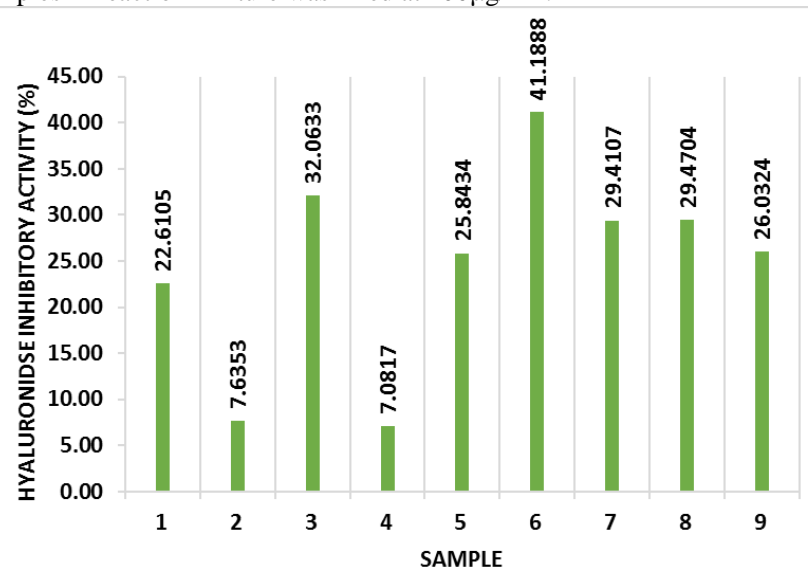

Fig. 4: Percentage of inhibitory hyaluronidase activity for all run using Hyaluronidase Assay.

(Necas et al., 2008). Since S.alata leaves shows inhibitory activity, these facts suggest that it may also offer a beneficial role in the management of allergies and inflammation, as therapeutic agents and application in ophthalmic surgery (Nor Hayati et al., 2016; Sahasrabudhe \& Deodhar, 2010; Kuppusamy et al., 1990; Necas et al., 2008).

The performance of the assay was verified using apigenin as a reference. Apigenin is one of widely used flavonols, a class in the flavonoids that consist of 4',5,7-dihydroxyflavone backbone (Figure 5). Apigenin was used as a representative compound in the assay due to its potent inhibitory effect on hyaluronidase. In fact, this study proves that apigenin is a dependable reference as the inhibitory hyaluronidase activity was approximately $73.9 \%$ at a concentration about $500 \mathrm{mM}$. Kuppusamy et al. (1990) has also claimed similar results. They observed that apigenin is one of the most potent flavonoids amongst tannin, luteolin and kaempferol with an inhibition up to $66.5 \%$ at concentration of $250 \mu \mathrm{M}$. Further, its inhibitory effects are two-fold more potent that other corresponding glycosides namely apiin, quercetin and rutin. This is due to the double bond between carbons 2 and 3 as well as the hydroxyl substituents at positions 5, 7 and 4' on the chemical structure which allow high anti-peroxidative properties. Further, the total flavonoid contents of the crude $\mathrm{SC}-\mathrm{CO}_{2}$ extract were investigated.

Quantitative determination of total flavonoids was calculated on the basis standard of rutin and linearity of the calibration curve was achieved between 10 to $50 \mathrm{ppm}$ concentration for rutin. ( $\mathrm{y}=$ $\left.0.0215 \mathrm{x}-0.0013 ; \mathrm{R}^{2}=0.924\right)$, shown in Figure 6. All extracts were investigated for flavonoids content except for Sample 3 (100 bar and $60^{\circ} \mathrm{C}$ ) due to insufficient amount of crude sample that was obtained from SFE. From Table 5, it can be observed that S.alata has temperature $\left(60^{\circ} \mathrm{C}\right)$ and pressure $(300 \mathrm{bar})$ rather than at mild conditions. At fixed pressure of 200 bar, the total flavonoid contents were noticed to be decreased at increasing temperature, as shown favourable amount of flavonoid contents is obtained after extracting was found highest for Sample 9 at 300 bar and $60^{\circ} \mathrm{C}$ (Figure 7). It<smiles>O=c1cc(-c2ccc(O)cc2)oc2cc(O)cc(O)c12</smiles>

Fig. 5: Chemical structure of apigenin.

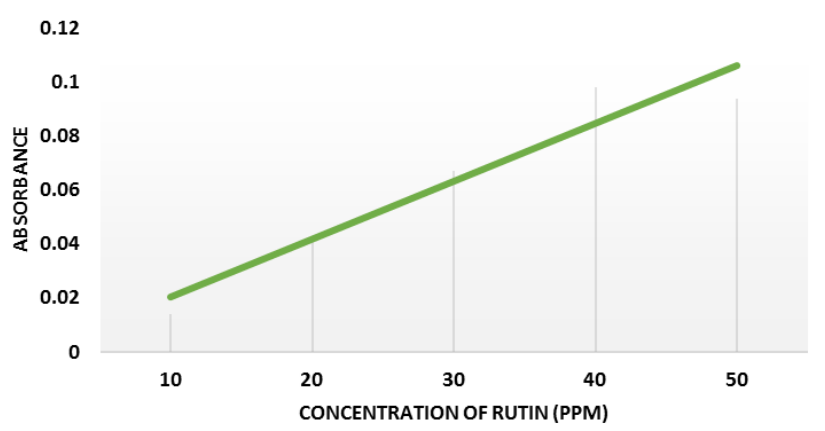

Fig. 6: Standard curve of rutin to determine total flavonoid contents of S.alata crude extract $\mathrm{y}=0.0215 \mathrm{x}-0.0013 ; \mathrm{R}^{2}=0.924$.

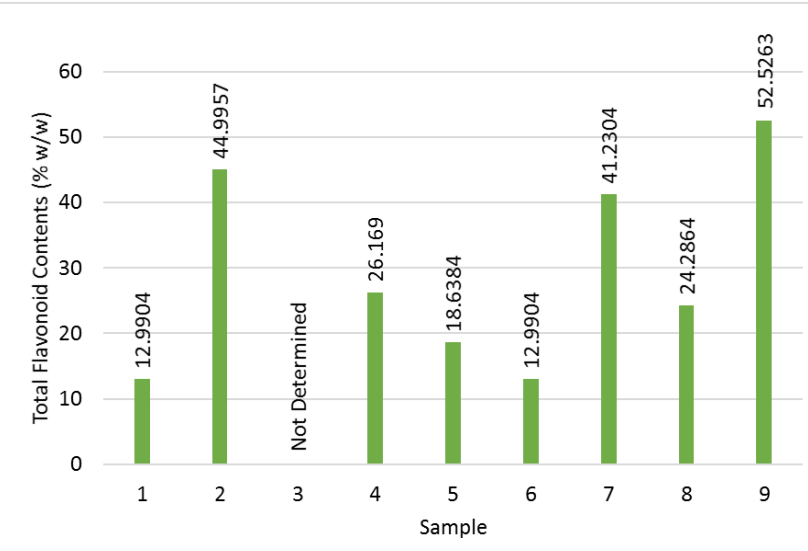

Fig. 7: Percentage of total flavonoid content for all samples. 
shows that flavonoids were preferable to be extracted at high with supercritical fluid carbon dioxide. The concentration of flavonoids throughout Sample 4 to Sample 6. It can be observed similar trend for Sample 7 and 8, at 40 and $50^{\circ} \mathrm{C}$ respectively at fixed pressure of 300 bar. However, the contents had increased at $60{ }^{\circ} \mathrm{C}$. This may be due to increased selectivity at high temperature and pressure (Liu et al., 2014). This proves that SC-CO $\mathrm{CO}_{2}$ extraction method is a viable and practical procedure for flavonoid compounds extraction. This can also open up new opportunities for supercritical extraction to isolate many other valuable compounds from plants that may be used in cosmetics, pharmaceutical and dermatological fields.

Currently, many researchers have shifted to using SFE rather than using solvents for extraction because SFE uses mild processing conditions, is readily separated from the solutes and recognized as safe by FDA and EFSA (Karale et al., 2011; Suetsugu et al., 2013) Hence, this make supercritical fluid a promising method to isolate flavonoid compounds from any type of plants. Flavonoids constitute an excellent antioxidant activity and thus, S.alata SFE crude extract makes a potential alternative for cosmetics as well as pharmaceutical industry due to diverse bioactivity such as preventing oxidant of low density lipoprotein and inhibit peroxidation of lipid (Rahman et al., 2008; Formica \& Regelson, 1995). Moreover, presence of the phenolic hydroxyl groups enable makes them a potent antioxidant that are able to scavenge the reactive oxygen species effectively (Cao et al., 1997). Further investigation of antioxidant activity of S.alata SFE crude extract can be determined by free radical scavenging DPPH procedures.

These preliminary results suggest that S.alata may possesses some anti-inflammatory properties through the inhibition of hyaluronidase. However, the moderate hyaluronidase inhibitory result from S.alata requires further investigation and optimization of supercritical fluid extraction parameters to enhance the inhibition activity and the extraction of valuable compounds without degrading the plant material and are economically efficient.

\section{Conclusion}

In this study, the optimum extraction conditions for supercritical fluid extraction to yield crude extract from S.alata dried leaves were not yet determined. According to the CCD and response surface analysis for SFE method, a quadratic polynomial model was used to model the yield of crude extract from a fixed mass of dried leaves $(130 \mathrm{~g})$ and a fixed $\mathrm{CO}_{2}$ flow rate $(35 \mathrm{~g} / \mathrm{min})$. The two independent variables involved in the prediction were pressure and temperature. The results indicated that the extraction pressure had the greatest impact on oil yield within the range of the operating conditions investigated. The highest yield was at the pressure of 300 bar and temperature of $60^{\circ} \mathrm{C}$, achieving a crude extract of $3.62 \%$. The results show that SFE was effective to obtain crude from S.alata. The biological analysis include hyaluronidase inhibition activity and total flavonoids content was successfully obtained for S.alata crude extract. The highest value obtained for S.alata for hyaluronidase inhibition activity was $41.19 \%$ (at P: 200 bar and $\mathrm{T}$ : $60^{\circ} \mathrm{C}$ ) while for total flavonoids content was $52.53 \%$ w/w (at P: 300 bar and T: $60^{\circ} \mathrm{C}$ ). Therefore, S.alata crude extract obtained with $\mathrm{SC}-\mathrm{CO}_{2}$ may have potential for use as an antiinflammation and antioxidant component in various dermatological and cosmetic industries. The application of $\mathrm{SC}-\mathrm{CO}_{2}$ as a safe solvent that can minimize wastewater compared to conventional techniques which uses organic solvents for extracting of oils from natural sources such methanol and ethanol. This method was effective in crude extraction yield and hence made supercritical fluid technology as an alternative technique for the extraction of pure and high quality crude from S.alata. It is a cost effective technique for laboratory scale and it seems to be appropriate for industrial crude/oil extraction. However, further study should be investigated for the optimization of both parameters pressure and temperature on the yield extract.

\section{Acknowledgement}

The authors would like to thank Universiti Teknologi MARA (UiTM) for funding this study and acknowledge the cooperation with Forest Research Institute Malaysia (FRIM) for technical support and providing information through the project.

\section{References}

[1] Abdalbasit, A. M., Siddiq, I. A., Mohamed, A. G. And Zeinab, S (2010). Supercritical Carbon Dioxide Extraction of Sorghum Bug (Agonoscelis pubescens) Oil Using Response Surface Methodology. Journal of the American Oil Chemical Society, 87, pp.849-856

[2] Alalor, C. A., Igwilo, C. I. And Jeroh, E. (2012). Assessment of Antifungal Potential of Aqueos and Methanol Extracts of Cassia alata. Asian Journal of Biological Sciences, doi: 103923/ajbs.2012

[3] Ali-Emmanuel, N., Moudachirou, M., Akakpo, J. A. and Quetin Leclercq, J. (2003). Treatment of bovine dermatophilosis with Senna alata, Lantana camara and Mitracarpus scaber leaf extracts. Journal of Enthnopharcology, Ireland, 86, pp.167-171

[4] Bimakr, M., Abdul Rahman, R., Taip, F. S., Mohd Adzahan, N., Sarker, M. Z. I. and Ganjloo, A. (2013). Supercritical Carbon Dioxide Extraction of Seed Oil from Winter Melon (Benincasa hispida) and its Antioxidant Activity and Fatty Acid Composition. Molecule, 18, pp.997-1014

[5] Brown, S. H. (2011). Senna alata. The Institute of Food and Agricultural Sciences, Florida. University of Florida. pp.1-2

[6] Cao, G., Sofic, E., and Prior, R. L. (1997). Antioxidant and prooxidant behavior of flavonoids: structure-activity relationships. Free Radical Biology and Medical, 22, pp.749-760

[7] Capuzzo, A., Maffei, M. E. and Occhipinti, A. (2013). Supercritical Fluid Extraction of Plant Flavors and Fragrances. Molecules, 18, pp 7194-7238, doi:10.3390/molecules18067194

[8] Chang, C., Yang, M., Wen, H. and Chern, J. (2002). Estimation of total flavonoid content in porpolis by two complementary colorimetric methods. Journal of Food and Drug Analysis, 10, pp.178182

[9] Chatterjee, S., Chatterjee, S. and Dutta, S. (2012). An Overview on the Ethnophytopathological Studies of Cassia alata - an Important Medicinal Plant and the Effect of VAM on its Growth and Productivity. International Journal of Research in Botany 2(4), pp.13-19

[10] Christman, S. (2008). Senna alata. Floridata Plant Encyclopedia.

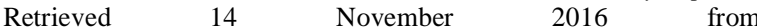
http://floridata.com/Plants/Fabaceae/Senna\%20alata/1097

[11] David, M. D. and Selber, J. N. (1996). Comparison of Extraction Techniques, Including Superciritical Fluid, High-Pressure Solvent, and Soxhlet, for Organophosphorus Hydraulic Fluids from Soil. Analytical Chemistry, USA, 68(17), pp.3038-3044

[12] Ehiowemwenguan, G., Inetianbor, J. E. and Yakubu, J. M. (2014). Antimicrobial Qualities of Senna alata. Journal of Pharmacy and Biological Sciences, 9(2), pp.47-52

[13] Elujoba, A. A., Ajulo, O. O. and Iweibo, G. O. (1989). Chemical and biological analyses of Nigerian Cassia species for laxative activity. Journal of Pharmaceutical \& Biomedical Analysis, Great Britain, 7(12), pp.1453-1457

[14] Enzymatic assay of hyaluronidase. (1996). Sigma-Aldrich. EC 3.2.1.36

[15] Formica, J.V. and Regelson, W. (1995). Review of the biology of quercetin and related bioflavonoids. Food Chemical and Toxicology, 33, pp.1061- 1080

[16] Gopalan, B., Goto, M., Kodama, A. and Hirose, T. (2000). Supercritical Carbon Dioxide Extraction of Turmeric (Curcuma longa). Journal of Agricultural and Food Chemistry, 48, pp.2189-2192

[17] Gritsanapan, W. and Mangmeesri, P. (2009). Standardized Senna alata Leaf Extract. Journal of Health Research, 23(3), pp.59-64

[18] Hong, C. E. and Lyu, S. Y. (2011). Genotoxicity detection of five medicinal plants in Nigeria. The Journal of Toxicological Sciences, 36(1), pp.87-93

[19] Kar, L. N., Chin, P. T., Oi, M. L., Kamariah, L. And Yaakob, C. M. (2009). Optimization of supercritical $\mathrm{CO}_{2}$ extraction 5 of phytosterol-enriched oil from Kalahari melon seeds. Food and Bioprocess Technology, DOI 10.1007/s11947-009-0253-4

[20] Karale, C. K., Dere, P. J., Honde, B. S., Kothule, S. and Kote, A. P. (2011). An overview on Supercritical Fluid Extraction for Herbal Drugs. International Journal of Pharmaceutical Innovations, 1(3), pp.93-105

[21] Lee, J. H. and Kim, G. H. (2010). Evaluation of Antioxidant and Inhibitory Activities for Different Subclasses Flavonoids on En- 
zymes for Rheumatoid Arthritis. Journal of Food Science, 75(7), pp.H212-H217

[22] Lepoyevic, I., Lepoyevic, Z., Pavlic, B., Ristic, M., Zekovic, Z., and Vidovic, S. (2017). Solid-liquid and high-pressure (liquid and supercritical carbon dioxide) extraction of Echinacea purpurea L. Journal of Supercritical Fluids, 119, pp.159-168

[23] Ling, S., Tanaka, T. and Kouno, I. (2003). Effects of Iridoids on Lipoxygenase and Hyaluronidase Activities and Their Activation by $\beta$-Glucosidase in the Presence of Amino Acids. Biology and Pharmaceutical Bulletin, Japan, 26(3), pp.352-356

[24] Liu, X., Yang, D. L., Liu, J. J., Xu, K. and Wu, G. H. (2014). Modeling of supercritical fluid extraction of flavonoids from Calycopteris floribunda leaves. Chemical Papers, 68(3), pp.316-323

[25] Marco, P., Vincenzo, S. and Biagio, M. (1998). A Comparison between the Chemical Composition of the Oil, Solvent Extract and Supercritical Carbon Dioxide Extract of Citrus media cv. Diamante. Journal of Essential Oil Research, 10(2), pp.145-152

[26] Menechini, F., Tundis, R., Bonesi, M., de Cindio, B., Loizzo, M. R., Conforti, F., Statti, G. A., Menabeni, R., Bettini, R., and Menechini, F. (2011). Chemical composition and bioactivity of Citrus medica L. cv. Diamante essential oil obtained by hydrodistillation, coldpressing and supercritical carbon dioxide extraction. Natural Product Research, 25(8), pp.789-799

[27] Mirofci, S. (2014). A Supercritical Fluid Extraction Process to Obtain Valuable Compounds from Eruca Sativa Leaves (Unpublished Master's thesis). University of Padua, Italy

[28] Mohideen, S., Sasikala, E., and Aruh, P. AJ. (2005). Pharmacognosy of Cassia Alata Linn-Leaves. Ancient Science of Life, XXIV(4), pp.192-198

[29] Montgomery, D. Design and Analysis of Experiments. John Wiley \& Sons, New York, (2001), pp:204-213

[30] Murthy, K. T. P. and Manohar, B. (2014). Optimization of Supercritical Carbon Dioxide Extraction of Phenolic Compounds from Mango Ginger Rhizome (Curcuma Amada Roxb.) Using Response Surface Methodology. Biomedicine and Biotechnology, 2(1), pp.1419

[31] Nautiyal, O. H. (2016). Food Processing by Supercritical Carbon Dioxide-Review. EC Chemistry, 2.1, pp. 111-135

[32] Necas, J., Bartosikova, P., Brauner, P. and Kolar, J. (2008). Hyaluronic acid (hyaluronan): a review. Veterinarni Medicina, 58(8), pp.397-411

[33] Owoyale, J. A., Olatunji, G. A., Oguntoye, S. O. (2005). Antifungal and Antibacterial Activities of an Alcoholic Extract of Senna alata Leaves. Journal of Applied Science and Environmental Management, 9(3), pp.105-107

[34] Pamulaparthi, A., Prathap, V. R., Banala, M. and Nanna, R. S (2016). Total Phenolic, Flavonoid contents and Antioxidant assays in leaf extracts of Senna alata (L.) Roxb. Journal of Pharmaceutical Sciences and Research, 8(9), pp.961-985

[35] Panichayupakaranant, P., Sakunpak, A. and Sakunphuek, A. (2009). Quantitative HPLC Determination and Extraction of Anthraquinones in Senna alata Leaves. Journal of Chromatographic Science, 47, pp.197-200

[36] Paulucci, V. P., Couto, R. O., Teixeira, C. C. C. and Freitas, L. A. P. (2013). Optimization of the extraction of curcumin from Curcuma longa rhizomes. Revista Brasileira de Farmacognosia, 23(1), pp.94-100

[37] Rahman, M. S. and Ali, M. Y. and Ali, M. U. (2008). In Vitro Screening Of Two Flavonoid Compounds Isolated From Cassia Alata L. Leaves For Fungicidal Activities. Journal of Bio-science, 16, pp.139-142

[38] Sahasrabudhe, A. and Deodhar, M. (2010). Anti-hyaluronidase, anti-elastase activity of garcinia indica. International Journal of Botanics, 6(3), pp.299-303

[39] Siti Hafsah, M. S., Zaibunnisa, A. H., Khudzir, I., Nooraain, H., and Wan Iryani, W. I. (2016). Optimization of Curcuma Longa L. Rhizome Supercritical Carbon Dioxide Extraction $\left(\mathrm{Sc}-\mathrm{CO}_{2}\right)$ by $\mathrm{Re}$ sponse Surface Methodology (RSM). Jurnal Teknologi, UTM, 78, pp. $87-92$

[40] Sumantran, V. N., Kulkarni, A. A., Harsulkar, A., Wele, A., Koppikar, S. J., Chandwaskar, R., Gaire, V., Dalvi, M. and Wagh, U. V. (2007). Hyaluronidase and collagenase inhibitory activities of the herbal formulation Triphala guggulu. Journal of Bioscience, 32, pp.755-761

[41] Wright, J. and DePhillipo, T. (2015). Comparison of Supercritical Fluid Extraction (SFE) and Pressurized Solvent Extraction (PSE) for the Recovery of gamma-Tocopherols in Walnut Oil. Waters Corporation, USA, 720003770EN

[42] Xiao, J. B., Chen, J. W. and Xu, M. (2007). Supercritical fluid $\mathrm{CO}_{2}$ extraction of essential oil from Marchantia convoluta: global yields and extract chemical composition. Electronic Journal of Biotechnology, Chile, 10(1), pp.1-8

[43] Zhang, H., Wang, Z., and Xu, S. (2007). Optimization of processing parameters for cloudy ginkgo (Ginkgo biloba Linn.) juice. Journal of Food Engineering, 80, pp.1226-1232 